\title{
Tempering Temperature Influence on 13Cr4Ni0.02C Steel Corrosion Resistance
}

\author{
Mérilin Cristina dos Santos Fernandes ${ }^{a}$, Sandra Nakamatsu ${ }^{b}$, Stephania Capellari De Rezende ${ }^{a}$, \\ Sylma Carvalho Maestrelli ${ }^{,}$Lucíola Lucena de Sousa ${ }^{a}$, Neide Aparecida Mariano * \\ ${ }^{a}$ Universidade Federal de Alfenas - UNIFAL, Campus Avançado de Poços de Caldas, Rod. José Aurélio \\ Vilela, BR 267-Km 533, Cidade Universitária, 377015-400, Poços de Caldas, MG, Brazil \\ ${ }^{b}$ Universidade Federal de Itajubá - UNIFEI, Instituto de Física e Química, Avenida BPS, 1303, 37500- \\ 903, Itajubá, $M G$, Brazil
}

Received: January 11, 2017; Revised: October 03, 2017; Accepted: October 05, 2017

\begin{abstract}
The thermal treatments employed in alloys are essential to obtaining desired microstructures and corrosion resistance properties. In this paper the low carbon martensitic steel $13 \mathrm{Cr} 4 \mathrm{Ni} 0.2 \mathrm{C}$ with different tempering temperatures was studied using potentiodynamic polarization technique in synthetic marine environment, in order to evaluate the effect of the tempering temperature on the steel corrosion resistance in an environment that simulates the conditions of use in oil and gas production. Microscopy results showed differences in the microstructure of tempered steel at low $\left(620^{\circ} \mathrm{C}\right)$ and high $\left(770^{\circ} \mathrm{C}\right)$ temperatures, indicating the appearance and extending of martensite laths with increasing temperature. Polarization tests showed that tempering temperature located between $620^{\circ} \mathrm{C}$ and $710^{\circ} \mathrm{C}$ indicated passive film formation and tempering temperatures of around $620{ }^{\circ} \mathrm{C}$ showed better resistance values to pitting corrosion.
\end{abstract}

Keywords: Martensitic stainless steel, Corrosion, Tempering, Pitting corrosion.

\section{Introduction}

Metallic alloys have different corrosion resistance levels and it is essential choosing a material that meets requirements of the oil and gas industry in deep waters to reduce maintenance needs or replacement during the lifetime of the equipment. Among types corrosion, localized pitting corrosion is very common in seawater and it is the most difficult process to control, especially when it comes to deepwater ${ }^{1}$.

Low carbon martensitic stainless steels have attracted great interest because of its good mechanical properties, excellent weldability, high corrosion resistance, ease of processing and lower costs, which is particularly attractive to the oil industry ${ }^{2-4}$. The equipment manufacturing sector for the oil extraction industry have increasingly used martensitic stainless steels to replace carbon steels and duplex stainless steels in applications such as casings, shafts and pump rotors ${ }^{5}$.

The corrosion resistance of stainless steels is directly associated with the formation of a protective film or passive layer on steel surface ${ }^{6}$. In stainless steels it is expected that this passive layer is generally rich in chromium film a few nanometers thick inhibiting corrosion ${ }^{7,8}$. In specific aggressive environments, stainless steels are susceptible to pitting corrosion because of the localized dissolution of the passive film and being that failure of metallic structures ${ }^{8-11}$. Pits in stainless steels are spaced apart and surface remains passive in the majority. Formation rate is very high and the pitting detection is very difficult due to small size, which demands certain time in order to be observed ${ }^{12}$.
Unlike other stainless steels, martensitic stainless steel properties could be changed by heat treatment of quenching and tempering ${ }^{13-16}$. The influence of tempering temperature on the corrosion resistance in marine environments is still poorly understood, even though the importance of $13 \mathrm{Cr}$ martensitic stainless steels and the microstructural transformations observed after heat treatments are widely studied ${ }^{17,18}$. These steels have complicated structure, requiring careful control for heat treatment to avoid carbide precipitation and ferrite delta formation in order to ensure complete transformation to homogeneous martensite, not to ferrite during the cooling stage $^{14}$. Steels are always quenched at temperatures $200^{\circ} \mathrm{C}$ higher than final temperature of austenite formation (about $800-850^{\circ} \mathrm{C}$ ) and then tempered near the initial temperature of austenite formation (about $\left.570-600^{\circ} \mathrm{C}\right)^{15}$.

Considering the challenges in understanding and relevance of the corrosion process of low carbon martensitic stainless steels it is presented a study in synthetic marine environment using cyclic potentiodynamic polarization in martensitic steel $13 \mathrm{Cr} 4 \mathrm{Ni} 0.02 \mathrm{C}$ tempering at different temperatures. The goal was investigate the relationship between tempering temperature and pitting corrosion resistance in an environment with high concentration of chlorides.

\section{Materials and Methods}

The $13 \mathrm{Cr} 4 \mathrm{Ni} 0.02 \mathrm{C}$ steel was melted in a conventional electric arc furnace with a refining process type AOD (Argon Oxygen Descarburization). The manufacture was 
made according to the standard ASTM A743-743M from the molten material and cast into sand molds agglomerated with phenolic-urethane resin, in the form of keel blocks. This alloy was received in the form of cylindrical specimens with $5 \mathrm{~cm}$ diameter and $25 \mathrm{~cm}$ length. The chemical composition obtained by inductively coupled plasma-atomic emission spectrometer (ICP/AES) for this steel is shown in Table 1.

The austenitic transformation temperatures $\left(\mathrm{A}_{\mathrm{cl}}\right.$ and $\left.\mathrm{A}_{\mathrm{c} 3}\right)$ and martensitic transformation temperatures $\left(\mathrm{M}_{\mathrm{i}}\right.$ and $\left.\mathrm{M}_{\mathrm{f}}\right)$ obtained by dilatometry by Mendonça et. $\mathrm{al}^{16}$ are shown in Table 2 .

Samples of the steel were quenched at $1000^{\circ} \mathrm{C}$ for two hours with subsequent tempering also for two hours at $590^{\circ} \mathrm{C}, 620^{\circ} \mathrm{C}, 650^{\circ} \mathrm{C}, 680^{\circ} \mathrm{C}, 710^{\circ} \mathrm{C}, 740^{\circ} \mathrm{C}$ and $770^{\circ} \mathrm{C}$ and cooling in air. Heat treatments were performed in a muffle furnace without protective atmosphere and the temperatures were monitored by using Chromel-Alumel thermocouple.

After the heat treatments, the samples were analyzed by scanning electron microscopy (SEM) and optical microscopy (MO), according to the ASTM E3-11 standard. The microstructure were etched with potassium metabisulfite $\left(\mathrm{K}_{2} \mathrm{~S}_{2} \mathrm{O}_{3}\right)$ modified Behara reagent. X-ray diffraction with $\mathrm{Cu}$ $\mathrm{Ka}$ radiation was also performed to determine the crystalline phases present.

Corrosion behavior was evaluated by cyclic potentiodynamic polarization method using a potentiostat Metrohm model Autolab/PGSTART302 connected to a typical electrochemical cell with a saturated calomel electrode (SCE) used as a reference electrode, a platinum plate employed as counterelectrode and the working electrode made from the steel studied. Electrochemical measurements were performed in triplicate for each condition. An aerated solution of synthetic marine environment was used in a concentration of 20,000 ppm $\mathrm{Cl}$ at room temperature prepared according to ASTM D1141-98. After immersion in the solution, the samples were subjected to conditions of open circuit potential (OCP). The potentiodynamic curves were measured at a potential scan rate of $1 \mathrm{mV} / \mathrm{s}$ with reversion of the direction when the anodic current density of $10^{-3} \mathrm{~A} / \mathrm{cm}^{2}$ was reached.

\section{Results and Discussion}

The low carbon martensitic stainless steel heat treated by quenching at $1000^{\circ} \mathrm{C}$ and tempered at temperatures of $590^{\circ} \mathrm{C}, 620^{\circ} \mathrm{C}, 650^{\circ} \mathrm{C}, 680^{\circ} \mathrm{C}, 710^{\circ} \mathrm{C}, 740^{\circ} \mathrm{C}$ and $770^{\circ} \mathrm{C}$ was characterized by optical and electron microscopy. Figure 1 shows the $13 \mathrm{Cr} 4 \mathrm{Ni} 0.02 \mathrm{C}$ alloy microstructure observed the microscope. Figure 1a presents the steel microstructure after quenching and Figure $1 \mathrm{~b}, 1 \mathrm{c}$ and $1 \mathrm{~d}$ after tempering at $620^{\circ} \mathrm{C}$, $680^{\circ} \mathrm{Cand} 770^{\circ} \mathrm{C}$, respectively. Black arrows indicate the martensitic matrix (M) and white arrows indicate the delta ferrite phase $(\delta)$ undissolved derived from gross melting.

In Figure 1a are observed plates of martensite and delta ferrite despite the small concentration of carbon in this steel. Delta ferrite formed by solidification or inadequate chemical compositions outside the equilibrium conditions is a controversial phase in this stee ${ }^{17,19}$. Since delta ferrite is formed it is difficult to be removed by conventional heat treatments (except for high annealing temperature) ${ }^{20}$. The images obtained by SEM confirmed change in martensitic matrix morphology increasing tempering temperature. While martensite is more dispersed at the tempering temperature of $620^{\circ} \mathrm{C}$ (Figure $1 \mathrm{~b}$ ), in samples tempering at $680^{\circ} \mathrm{C}$ and $710^{\circ} \mathrm{C}$ (Figure $1 \mathrm{c}$ and $1 \mathrm{~d}$ ) it was possible to see its martensitic phase shaped laths. Figure 2 shows the delta ferrite $(\delta)$ with precipitates in the boundary for the sample at $770^{\circ} \mathrm{C}$.

The open circuit potential (OCP) and cyclic potentiodynamic polarization (PPC) curves obtained for $13 \mathrm{Cr} 4 \mathrm{Ni} 0.02 \mathrm{C}$ steel is shown in Figure 3.

The curve of the open circuit potential versus time is able to show the metal behavior in the electrolytic environment. If the curve shows positive trends, there was formation of a passive film on the material surface; if negative trends, may mean that there was a widespread corrosion. It can be seen in Figure $3 \mathrm{a}$ the passive film formation at the tempering temperature between $620^{\circ} \mathrm{C}$ and $710^{\circ} \mathrm{C}$, since temperatures below $\left(590^{\circ} \mathrm{C}\right)$ or above these $\left(740^{\circ} \mathrm{C}\right.$ and $\left.770^{\circ} \mathrm{C}\right)$ indicated values with negative trends and a possible widespread corrosion or higher difficulty in the passive film formation.

It is possible to observe in Figure $3 \mathrm{~b}$ that in none tempering temperatures the samples suffered negative hysteresis, which means that all samples had the passive layer ruptured and subsequent pits formation. Furthermore, when the curve has a well-defined passive region it means that the passive oxide film suffered slower corrosion and when there is a very small region it means may have occurred a potential pits nucleation, showing that the material suffered a faster corrosion. Based on this analysis and by comparing the curves in Figure 3b, it can be conclude that tempering temperature affected the results and proved that temperatures between $620^{\circ} \mathrm{C}$ and $710^{\circ} \mathrm{C}$ obtained the better-defined passive region.

Table 1. Chemical compositions of the steel (wt. \%).

\begin{tabular}{ccccccc}
\hline Sample & $\mathbf{C}$ & $\mathbf{S i}$ & $\mathbf{M n}$ & $\mathbf{C r}$ & $\mathbf{N i}$ & Mo \\
\hline $13 \mathrm{Cr} 4 \mathrm{Ni} 0.02 \mathrm{C}$ & 0.03 & 1.00 & 0.70 & 13.00 & 4.12 & 0.72 \\
\hline
\end{tabular}

Table 2. Temperatures of the steel transformations $\left({ }^{\circ} \mathrm{C}\right)$.

\begin{tabular}{ccccc}
\hline Steel & $\mathbf{A}_{\mathbf{c} 1}$ & $\mathbf{A}_{\mathbf{c} 2}$ & $\mathbf{M}_{\mathbf{i}}$ & $\mathbf{M}_{\mathbf{f}}$ \\
\hline 13Cr4Ni0.02C & 756 & 836 & 234 & 167 \\
\hline
\end{tabular}




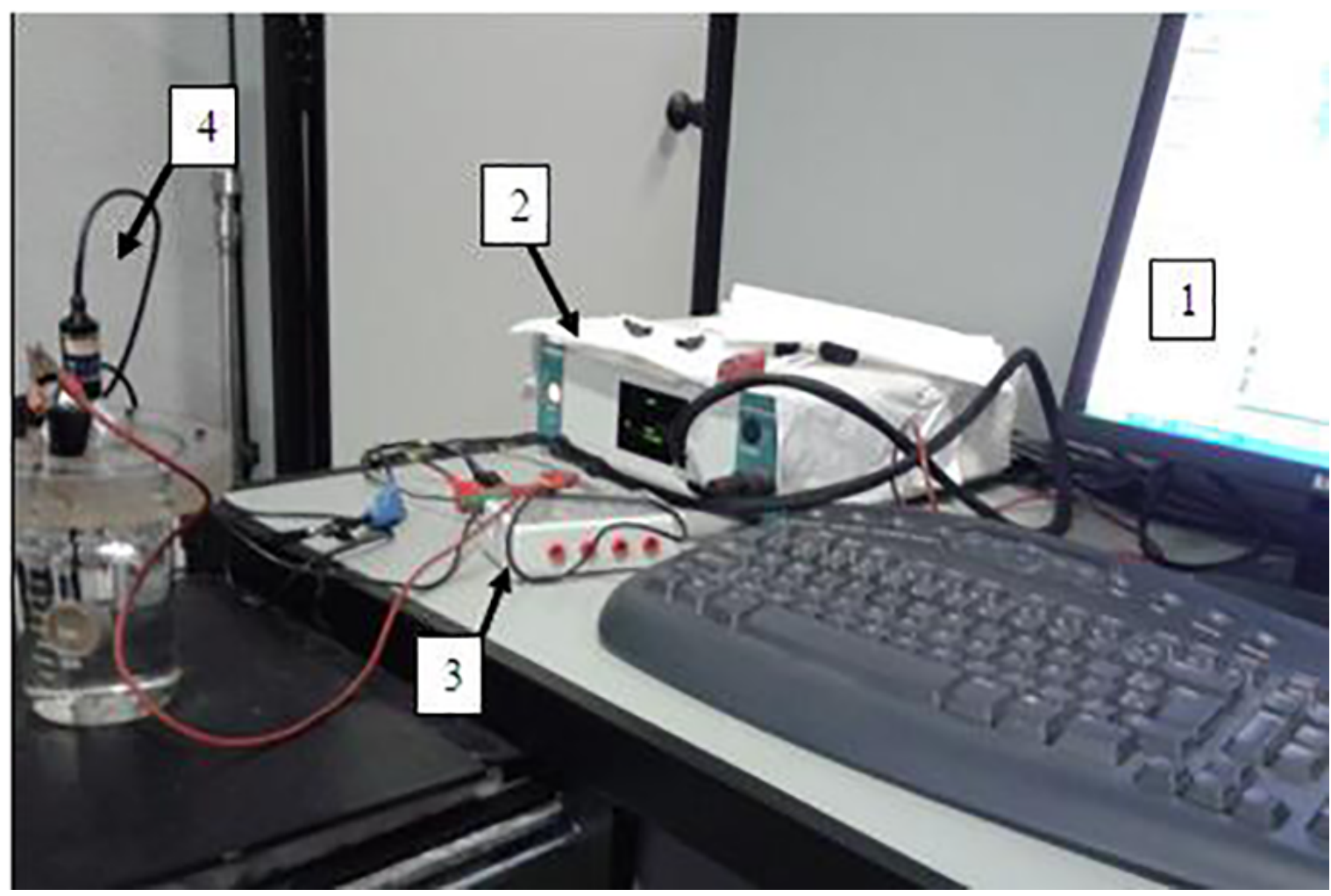

Figure 1. Micrograph of the $13 \mathrm{Cr} 4 \mathrm{Ni} 0.02 \mathrm{C}$ martensitic steel. a) obtained by optical microscopy of the sample quenched at $1000^{\circ} \mathrm{C}$; b) obtained by SEM of the sample tempered at $620^{\circ} \mathrm{C}$; c) obtained by SEM of the sample tempered at $680^{\circ} \mathrm{C}$; d) obtained by SEM of the sample tempered at $710^{\circ} \mathrm{C}$.

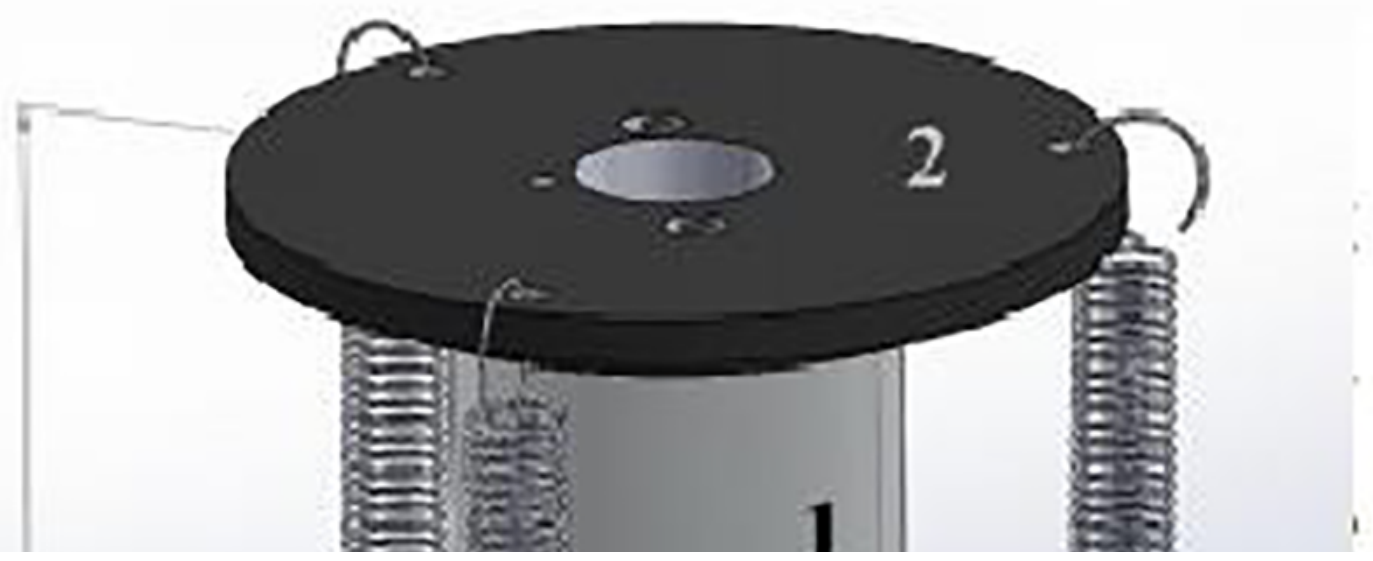

Figure 2. Micrograph of the $13 \mathrm{Cr} 4 \mathrm{Ni} 0.02 \mathrm{C}$ martensitic steel obtained by $\mathrm{SEM}$ of the sample tempered at $770^{\circ} \mathrm{C}$. a) Region with delta ferrite phase. b) Precipitate detail on the delta ferrite boundary. 

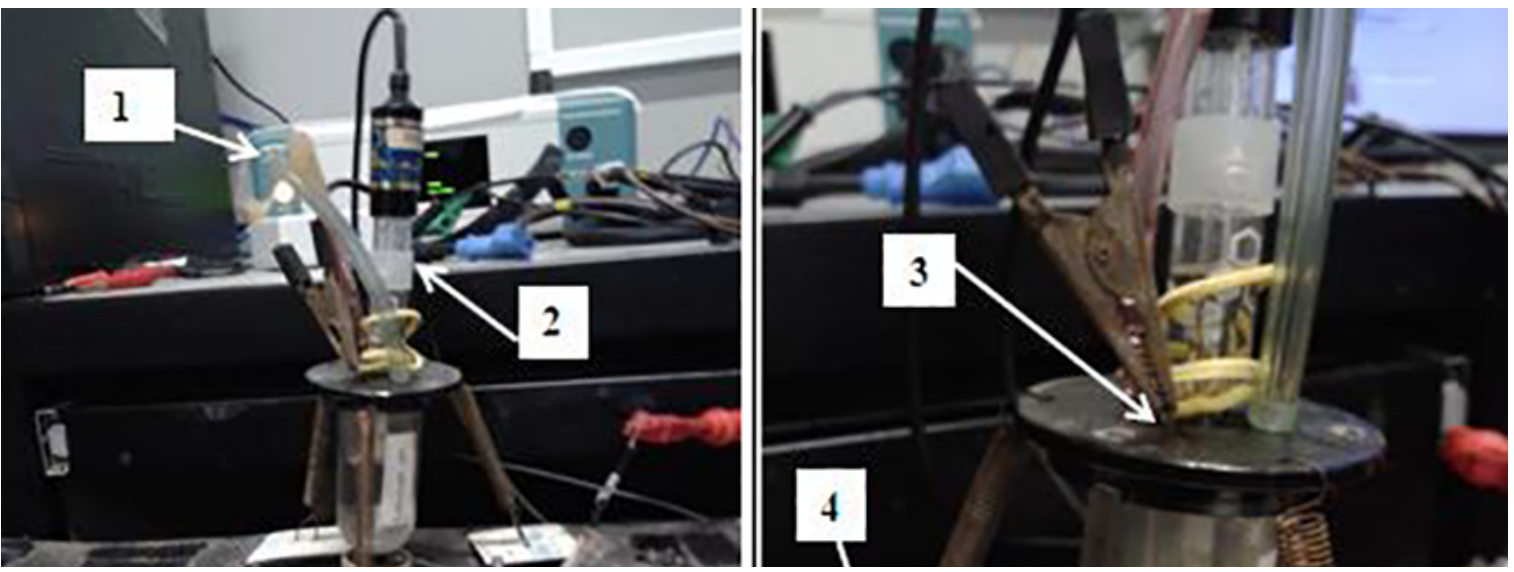

Figure 3. Curves obtained in the corrosion test in marine environment to $20,000 \mathrm{ppm} \mathrm{Cl}^{-}$of the $13 \mathrm{Cr} 4 \mathrm{Ni} 0.02 \mathrm{C}$ steel. (a) $\mathrm{OCP}$; (b) $\mathrm{CPP}$.

Table 3. Electrochemical parameters of the $13 \mathrm{Cr} 4 \mathrm{Ni} 0.02 \mathrm{C}$ steel.

\begin{tabular}{ccccc}
\hline $\begin{array}{c}\text { Tempering } \\
\text { Temperature }\left({ }^{\circ} \mathbf{C}\right)\end{array}$ & $\mathbf{E}_{\text {corr }}(\mathbf{V})$ & $\mathbf{E}_{\text {pite }}(\mathbf{V})$ & $\mathbf{I}_{\text {pp }}\left(\mathbf{A} / \mathbf{c m}^{2}\right)$ & $\mathbf{E}_{\text {prot }}(\mathbf{V})$ \\
\hline 590 & -0.373 & -0.103 & $7.01 \mathrm{E}-6$ & -0.313 \\
620 & -0.350 & 0.032 & $6.58 \mathrm{E}-6$ & -0.285 \\
650 & -0.390 & -0.060 & $4.37 \mathrm{E}-6$ & -0.337 \\
680 & -0.373 & 0.027 & $8.61 \mathrm{E}-6$ & -0.308 \\
710 & -0.359 & -0.221 & $3.80 \mathrm{E}-6$ & -0.202 \\
740 & -0.432 & -0.086 & $5.17 \mathrm{E}-6$ & -0.350 \\
770 & -0.355 & -0.159 & $4.50 \mathrm{E}-6$ & -0.206 \\
\hline
\end{tabular}

From the curves of Figure $3 \mathrm{~b}$ were determined the electrochemical potentials of $13 \mathrm{Cr} 4 \mathrm{Ni} 0.02 \mathrm{C}$ steel samples. When passive anodic region is broken in advance, occurs pitting corrosion. In CPP curves the pite results in a noticeable increase in the current density and leads to called pitting potential (Epit). The higher this parameter, the greater pitting corrosion resistance of the material. Protective potential (Eprot) occurs when the curve crosses itself and implies that below this potential there is no possibility to break the passive film and no more will occur pitting formation. Corrosion potential (Ecorr) indicates when the stainless steel corrosion begins, since in this potential the oxidation rate is equal to the reduction rate. The Ipp value shows the passivation stream for each tempering temperature. All determined parameters are described in Table 3.

Analyzing the pitting potential of Table 3, it can be seen that the tempering temperature of $620^{\circ} \mathrm{C}$ presented the highest value of corrosion resistance per pite, supporting the analysis made of OCP curves, which indicates that the tempering temperature affects the corrosion resistance of 13Cr4Ni0.02C martensitic stainless steel. To explain this result X-ray diffraction (XRD) analyzes were carried out, with the $620^{\circ} \mathrm{C}$ and $770^{\circ} \mathrm{C}$ spectra being shown in Figure 4.

In Figure 4 only the sample tempered at $620^{\circ} \mathrm{C}$ shows the retained austenite presence and the spectrum obtained

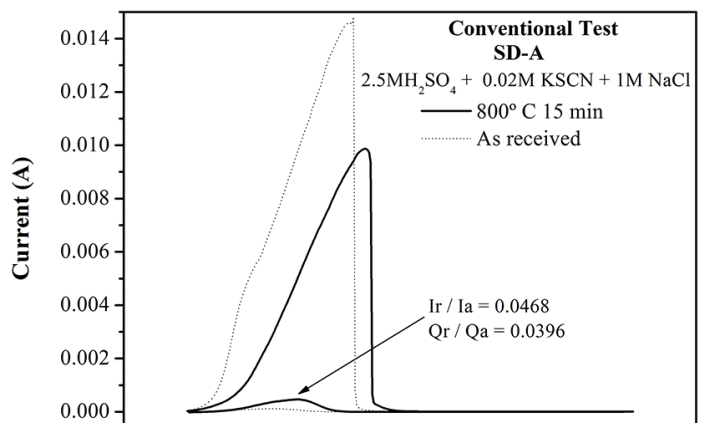

Figure 4. X-ray diffraction spectrum of the samples tempered at $620^{\circ} \mathrm{C}$ and $770^{\circ} \mathrm{C}$.

Table 4. Phases and pitting potential obtained at different tempering temperatures.

\begin{tabular}{cccc}
\hline $\begin{array}{c}\text { Tempering } \\
\text { Temperature }\left({ }^{\circ} \mathbf{C}\right)\end{array}$ & Phases & $\mathbf{\delta ( \% )}$ & $\mathbf{E}_{\text {pite }}(\mathbf{V})$ \\
\hline 590 & $\mathrm{M} ; \delta$ & -- & -0.103 \\
620 & $\mathrm{M} ; \delta ; \gamma$ & $1.40 \pm 0.53$ & 0.032 \\
650 & $\mathrm{M} ; \delta$ & $2.54 \pm 0.53$ & -0.060 \\
680 & $\mathrm{M} ; \delta$ & $1.53 \pm 0.60$ & 0.027 \\
710 & $\mathrm{M} ; \delta$ & $2.24 \pm 0.54$ & -0.221 \\
740 & $\mathrm{M} ; \delta$ & $1.88 \pm 0.17$ & -0.086 \\
770 & $\mathrm{M} ; \delta$ & $2.63 \pm 0.60$ & -0.159 \\
\hline
\end{tabular}


to the sample tempered at $770^{\circ} \mathrm{C}$ is identical for the other temperatures. Table 4 shows the phases obtained by XRD and the delta ferrite fraction (in \%) as a function of the tempering temperatures calculated by an image analysis software - Quantikov.

The 13CrNiMo low carbon martensitic stainless steels has a direct relationship between pitting susceptibility and the volume fraction of retained austenite. The retained austenite can have beneficial effects on the corrosion resistance, because it favors chromium and molybdenum carbonitrides dissolution, increasing the content of these elements in the matrix. According to Bilmes et al. ${ }^{21}$ the pitting corrosion mechanism can also be associated with crack propagation, in which cracks propagate from the martensite phase to the austenite phase, ductile and stable, making them difficult to spread. Thus, the higher austenite volume fraction in tempered conditions, the lower pitting susceptibility ${ }^{5,22}$. The presence of delta ferrite leads to a decrease in pitting corrosion potential, because chromium contained in the matrix migrates to the delta ferrite boundary, impoverishing the matrix and damaging the passive layer formation ${ }^{19,23}$. This fact can be observed in details in Figure 2.

\section{Conclusions}

Microstructures of the $13 \mathrm{Cr} 4 \mathrm{Ni} 0.02 \mathrm{C}$ steel undergone significant changes with the tempering temperature variation. The main one was the extension of the martensite slats and its order within the grains, besides the appearance of precipitates in the ferrite delta boundary. The tempering temperature also influences the values of electrochemical parameters steel. The cyclic potentiodynamic polarization tests in marine environment containing 20,000 ppm $\mathrm{Cl}$ ions indicated the tempering temperature around of $620^{\circ} \mathrm{C}$ was satisfactory, since at this temperature the highest positive value of pitting potential was obtained. The steel tempering at $620^{\circ} \mathrm{C}$ was the only one that presented retained austenite, corroborating with the best pitting corrosion resistance obtained among the studied temperatures.

\section{Acknowledgements}

The authors acknowledge to FAPEMIG, CNPq, CAPES and FAPESP.

\section{References}

1. Anselmo N, May JE, Mariano NA, Nascente PAP, Kuri SE. Corrosion behavior of supermartensitic stainless steel in aerated and $\mathrm{CO}_{2}$-saturated synthetic seawater. Materials Science and Engineering: A. 2006;428(1-2):73-79.

2. Yin ZF, Wang XZ, Liu L, Wu JQ, Zhang YQ. Characterization of Corrosion Product Layers from $\mathrm{CO}_{2}$ Corrosion of $13 \mathrm{Cr}$ Stainless Steel in Simulated Oilfield Solution. Journal of Materials Engineering and Performance. 2011;20(7):1330-1335.
3. Liu YR, Ye D, Yong QL, Su J, Zhao KY, Jiang W. Effect of Heat Treatment on Microstructure and Property of Cr13 Super Martensitic Stainless Steel. Journal of Iron and Steel Research, International. 2011;18(11):60-66.

4. Lei XW, Feng YR, Fu AQ, Zhang JX, Bai ZQ, Yin CX, et al. Investigation of stress corrosion cracking behavior of super $13 \mathrm{Cr}$ tubing by full-scale tubular goods corrosion test system. Engineering Failure Analysis. 2015;50:62-70.

5. Turnbull A, Griffiths A. Corrosion and cracking of weldable 13 wt- $\%$ Cr martensitic stainless steels for application in the oil and gas industry. Corrosion Engineering, Science and Technology. 2003;38(1):21-50.

6. Mu LJ, Zhao WZ. Investigation on carbon dioxide corrosion behaviour of HP13Cr110 stainless steel in simulated stratum water. Corrosion Science. 2010;52(1):82-89.

7. Bastidas JM, Torres CL, Cano E, Polo JL. Influence of molybdenum on passivation of polarized stainless steels in a chloride environment. Corrosion Science. 2002;44(3):625-633.

8. Newman RC. Understanding the Corrosion of Stainless Steel. Corrosion. 2001;57(12):1030-1041.

9. Hara T, Asahi H, Kawakami A, Takhashi A. Effects of Alloying Elements on Carbon Dioxide Corrosion in $13 \%$ to $20 \%$ Chromium-Containing Steels. Corrosion. 2000;56(4):419-428.

10. Park JO, Matsch S, Böhni H. Effect of Temperature and Chloride Concentration on Pit Initiation and Early Pit Growth of Stainless Steel. Journal of the Electrochemical Society. 2002;149(2):B34-B39.

11. Mori G, Bauernfeind D. Pitting and crevice corrosion of superaustenitic stainless steels. Materials and Corrosion. 2004;55(3):164-173.

12. Pistorius PC, Burstein GT. Metastable pitting corrosion of stainless steel and the transition to stability. Philosophical Transactions of the Royal Society A. 1992;341(1662):531-559.

13. Isfahany AN, Saghafian H, Borhani G. The effect of heat treatment on mechanical properties and corrosion behavior of AISI420 martensitic stainless steel. Journal of Alloys and Compounds. 2011;509(9):3931-3936.

14. Park JY, Park YS. The effects of heat-treatment parameters on corrosion resistance and phase transformations of $14 \mathrm{Cr}-3 \mathrm{Mo}$ martensitic stainless steel. Materials Science and Engineering: A. 2007;449-451:1131-1134.

15. Song Y, Li X, Rong L, Li Y. Anomalous Phase Transformation from Martensite to Austenite in Fe- $13 \% \mathrm{Cr}-4 \% \mathrm{Ni}-\mathrm{Mo}$ Martensitic Stainless Steel. Journal of Materials Science \& Technology. 2010;26(9):823-826.

16. Mendonça R, Cronemberger MER, Santos MT, Mariano NA. Estudo do efeito do revenido em aços inoxidáveis martensíticos: $13 \mathrm{Cr} 4 \mathrm{Ni} 0.02 \mathrm{C}, 13 \mathrm{Cr} 2 \mathrm{Ni} 0.1 \mathrm{C}$ e $13 \mathrm{Cr} 1 \mathrm{Ni} 0.15 \mathrm{C}$. In: Proceedings of the $68^{\text {th }}$ ABM International Annual Congress; 2013 Jul 30Aug 2; Belo Horizonte, MG, Brazil. São Paulo: ABM; 2013 , p. 4203-4209.

17. Bilmes PD, Solari M, Llorente CL. Characteristics and effects of austenite resulting from tempering of $13 \mathrm{Cr}$-NiMo martensitic steel weld metals. Materials Characterization. 2001;46(4):285296. 
18. Lei X, Feng Y, Zhang J, Fu A, Yin C, Macdonald DD. Impact of Reversed Austenite on the Pitting Corrosion Behavior of Super 13Cr Martensitic Stainless Steel. Electrochimica Acta. 2016;191:640-650.

19. Gesnouin C, Hazarabedian A, Bruzzoni P, Ovejero-Gzracia J, Bilmes PD, Llorente C. Effect of post-weld heat treatment on the microstructure and hydrogen permeation of $13 \mathrm{CrNiMo}$ steel. Corrosion Science. 2004;46(7):1633-1647.

20. Kim SH, Moon HK, Kang T, Lee CS. Dissolution kinetics of delta ferrite in AISI 304 stainless steel produced by strip casting process. Materials Science and Engineering: A. 2003;356(12):390-398.
21. Bilmes PD, Llorente CL, Saire Huamán L, Gassa LM, Gervasi CA. Microstructure and pitting corrosion of $13 \mathrm{CrNiMo}$ weld metals. Corrosion Science. 2006;48(10):3261-3270.

22. Gervasi CA, Méndez, CM, Bilmes PD, Llorente CL. Analysis of the impact of alloy microstructural properties on passive films formed on low-C 13CrNiMo martensitic stainless steels. Materials Chemistry and Physics. 2011;126(1-2):178-182.

23. Moon J, Ha HY, Lee TH. Corrosion behavior in high heat input welded heat-affected zone of $\mathrm{Ni}$-free high-nitrogen $\mathrm{Fe}-18 \mathrm{Cr}$ $10 \mathrm{Mn}-\mathrm{N}$ austenitic stainless steel. Materials Characterization . 2013;82:113-119. 